\title{
Altered pattern in viral mRNA expression of Iranian type HTLV-1 leading to enhanced viral expression
}

\author{
Takaharu Ueno $^{1 *}$, Runze Xun ${ }^{1}$, Mineki Saito ${ }^{2}$, Kenta Tezuka', Yuetsu Tanaka ${ }^{3}$, Jun-ichi Fujisawa ${ }^{1}$ \\ From 16th International Conference on Human Retroviruses: HTLV and Related Viruses \\ Montreal, Canada. 26-30 June 2013
}

Risk for HAM/TSP development is known to differ among the subtypes of HTLV-1. In Japan, incident rate of HAM/ TSP in carrier people infected with cosmopolitan type A is 2.5 times higher than those with cosmopolitan type B. Although HTLV-1 of cosmopolitan type A is also prevalent in Jamaica and northern part of Iran, the rate of HAM/TSP development in this area is much higher than in Japan. Several polymorphisms in nucleotide sequence were found in $\mathrm{pX}$ region in Jamaican and Iranian type A compared to those in Japanese type A. These sequences include the substitution of stop codon to Trp codon, leading to extension of 20 a.a. in C-terminal of Rex. To assess the effect of these sequences on viral replication, we constructed the infectious clone harboring either Japanese type A (JP) or Jamaican/Iranian $(\mathrm{J} / \mathrm{I}) \mathrm{pX}$ sequences. Viral production from infectious clones in transiently transfected $293 \mathrm{~T}$ cells was evaluated by p19 ELISA assay and J/I type virus was found to be produced higher than JP type. The virus produced in 293T cells was used to establish HTVL-1 infected Jurkat cell lines and viral mRNA expression was analyzed. In J/I type cell lines, full length mRNA was expressed more than doublyspliced pX mRNA, whereas JP type cell lines exhibited the opposite pattern of mRNA expression. These results indicate that the higher viral production of J/I type should result from distinct post-transcriptional control most provably due to the difference in Rex protein. We are currently investigating the molecular mechanism of this phenomenon.

\section{Authors' details}

'Department of Microbiology, Kansai Medical University, Hirakata, Osaka, Japan. ${ }^{2}$ Department of Microbiology, Kawasaki Medical School, Kurashiki,

\footnotetext{
* Correspondence: uenotak@takii.kmu.ac.jp

'Department of Microbiology, Kansai Medical University, Hirakata, Osaka, Japan

Full list of author information is available at the end of the article
}

Okayama, Japan. ${ }^{3}$ Department of Immunology, Graduate School of Medicine, University of the Ryukyus, Nishihara, Okinawa, Japan.

Published: 7 January 2014

doi:10.1186/1742-4690-11-S1-P146

Cite this article as: Ueno et al: Altered pattern in viral mRNA expression of Iranian type HTLV-1 leading to enhanced viral expression.

Retrovirology 2014 11(Suppl 1):P146.
Submit your next manuscript to BioMed Central and take full advantage of:

- Convenient online submission

- Thorough peer review

- No space constraints or color figure charges

- Immediate publication on acceptance

- Inclusion in PubMed, CAS, Scopus and Google Scholar

- Research which is freely available for redistribution

Submit your manuscript at www.biomedcentral.com/submit
() Biomed Central 